\title{
Is there a Microbial Loop in Lake Baikal?
}

\author{
Manfred Bölter** and Lyubov R. Izmest'yevab \\ ${ }^{a}$ Institute for Polar Ecology, University Kiel, \\ 1-3 Wischhofstr, Kiel, 24148 Germany \\ ${ }^{b}$ Scientific Research Institute of Biology \\ of Irkutsk State University, \\ PO Box 24, Irkutsk-3, 664003 Russia ${ }^{1}$
}

Received 7.06.2012, received in revised form 14.06.2012, accepted 21.06.2012

The occurrence of a microbial loop in the pelagic environment is discussed with regard to hydrological and meteorological effects as well as to the planktological states during the seasons in lake Baikal. Strong local conditions due the melting ice and the sequence of the spring bloom indicate close local interactions between phytoplankton and bacteria. However, missing reports on micro-zooplankton and continuous reports of the roles of the individual organism groups involved in the microbial loop make is difficult to establish the way of matter flow in the lake as a general path. Further, sinking rates of diatoms do not allow a remineralisation of plankton- $C$ and $-N$ in the deep water in its upper photic levels. Thus, microbial mineralized nutrients will stay for long time in the abyssal area of the lake, which can be regarded responsible for its oligotrophic nature in the upper layers.

Keywords: Lake Baikal, limnology, microbial loop.

\section{Introduction}

The pelagic system of Lake Baikal is governed by a strong seasonality, great depth and an enormous water body and counts as the largest limnological environment on the Earth. The lake stretches more than $600 \mathrm{~km}$ from north to south and thus covers different climatic zones, strongly expressed by the shift in the timing of ice melting in spring / early summer. Another special character is the isolated locality with only small exchange to other water bodies, thus, many endemic species at all trophic levels evolved. This has formed not only special organisms but also raises the question whether this system has also peculiarities in its ecology and trophic interactions.

A special topic arises about the functioning of the lower organism's food web and its role in production and mineralization. Two scenarios about the pelagic biological processes can be discussed, on the one hand, the traditional sequential food web inclusive its detritus food

\footnotetext{
Corresponding author E-mail address: mboelter@ipoe.uni-kiel.de (C) Siberian Federal University. All rights reserved
} 
web (Wetzel, 2001), on the other hand, the more complex web with various interactive links inclusive the microbial loop (Azam et al., 1983).

\section{The pelagic conditons}

The discussion about the pelagic food web in Lake Baikal has been regarded for long time in way of the first scenario, i.e., a step wise trophic food chain, starting with primary producers, mainly diatoms, continuing with herbivorous and carnivorous zooplankton, and ending up with fish, the Baikal seal as a top predator and men. This traditional view has also been accepted for marine systems, e.g., Steel (1974). However, Steel concluded from his fish production studies at marine shelves where he thought about is a missing link in the food web, which later has been recognized as the microbial loop.

In the marine system, two further insights were gained some time ago, which fit later well into the picture of the microbial loop:

i) the two different kinds of primary production, new and regenerated production (Dugdale, Goering, 1967), and

ii) the influence of mechanical energy transfers (Margalef, 1979).

Further, the microbial loop can only work properly with an active community of protozooplankton and, certainly, with a significant contribution of dissolved organic matter which is available to heterotrophic bacteria, generally known as exudates. The question now is: are these items necessary for scenario $i$ or ii present in all its facets in Lake Baikal by which the ecosystem can be describe properly by the one or other picture.

Consequently, the following issues have to be tackled when describing the pelagic processes and following the introduction question about the Lake's way of working:
- physical features of the euphotic zone;

- interactions between water and sediments, i.e., benthic nutrient recycling and benthic pelagic coupling;

- sources (nutrients) for the spring bloom and its dominant phytoplankton;

- features and roles of bacteria during this step in pelagic production;

- role of dissolved organic matter, its source (exudates) and availability;

- seasonal successions of dominant phytoplankton species and communities;

- succession of zooplankton communities;

- fate of particulate organic material, sedimentation and regeneration process;

- which peculiarities are known for Lake Baikal that might make it as a special ecological system?

The structure of the euphotic zone and nutrient regeneration is regulated by physical processes, i.e., stratification, turbulence, upwelling etc. Operationally, Lake Baikal can be divided into three zones, the north, the central and the south basin, just from its bathymetry (Kozhov, 1962; Semovski, 2000). Each of them show individual thaw behaviour in spring and thus different temporal structures in water masses (Killworth et al., 1996; Hohmann et al., 1997) and subsequent shifts in biological processes (Heim et al., 2005), which has been documented by differences in organic material from sedimentation traps by its distinct lipid compositions (Russell, Russell-Mele, 2005) and lead to the question of differences in autochthonous productivity. The pelagic stratification is then reflected by increases in cell numbers of phytoplankton (Jewson et al., 2008). Temperature has been proposed as a driving factor for phytoplankton succession (Richardson et al., 2000), but it seems more likely, as temperature is triggered by radiation and this, in turn, stimulates primary production. 


\section{Biological effects}

The maintenance of diatoms in the photic zone, which is important for their primary production, can be increased by turbulence from wind and subsequent mixing during spring. The necessity of such turbulence for maintaining diatom production has been described by Margalef (1979). A simulation of disturbance of Lake Baikal actually influenced positively phytoplankton biomass and zooplankton fluctuations (Silow et al., 2001). Turbulent patches are variable in size and time. Wüest and Lorke (2010) found those on scales of $100 \mathrm{~m}$ in Lake Baikal.

Some special and local features like thermal bars are able to transport water masses and nutrients to deeper layers (Shimaraev et al., 1993), and locally they can be of great importance for the water mass (and nutrient) budget (Melnik et al., 2006). Such water of elevated salinity is also responsible for bottom water formation (Kipfer et al., 1996), and stimulates bottom currents and lateral transport of dissolved and particulate matter.

Further, the influences of river inputs have to be taken into accounts due to their input of energy and inorganic matter as well as allochthonous sources, like particulate and dissolved organic carbon, bacteria and microbiological processes (Yoshioka et al., 2002; Maksimenko et al., 2008). The input of allochthonous organic $C$ is considered to be nearly $300 \mathrm{kt} \mathrm{C} \mathrm{yr}^{-1}$ (Granina, 1997). This holds also true for the main elements of earth alkali metals (Callender, Granina, 1997), and silicon shows highest accumulation rates in sediments and transport rates from rivers. A study of Hohmann et al. (1997) showed the significant influence of Selenga plume for deepwater renewal.

\section{Seasonal effects}

The start of the spring bloom is regulated by the increasing light system, and the ice thaw from south to north. This bloom starts early in spring with the growth of Aulacoseira baicalensis or A. skvortzowii under the ice (Mackay et al., 2003). This is well confirmed by other reports, e.g., Fietz et al. (2005a), Shimaraeva et al. (2010) who report that this period is strongly dominated by diatoms, here Stephanodiscus meyerii and A. baicalensis, and Chrysophyceae.

During summer (July to September) blooms of small unicellular cyanobacteria were found, dominated by Synechococcus sp. or Synechocystis sp. (Belykh, Sorokovikova, 2003; Belykh et al., 2006). The numbers of $10^{6}$ cells $\mathrm{ml}^{-1}$ are close to numbers of heterotrophic bacteria or even exceeding them (Nagata et al., 1994; Straskrabova et al., 2005; Ahn et al., 2006). Summer blooms were also described by dominance of Chlorophyta (Koliella and Monoraphidium) as well as flagellates (Fietz et al., 2005; Izmestyeva, Silow, 2010). During this time of strong stratification also Synechocystis limnetica was found to dominate the pelagial of the south basin (Mackay et al., 2003), an autumn bloom again can be formed again by $A$. baicalensis or other diatoms (Galazi et al., 1978; Ryves et al., 2003). Further, Rhodomonas pusilla, a Cryptophyceae species, and Chrysophyceae have been observed (Fietz et al., 2005a; Izmestyeva, Silow, 2010).

The great variability on diatom communities seems to be special feature of this lake, triggered by various environmental parameters (Popovskaya, 2000). The recurrent pattern of a picoplankton bloom, dominated by cyanobacteria during summer can be triggered by a stable stratification and $N$-depletion, which hampers phytoplankton growth, but favours a self-sustaining $N$-fixing community during this time. The vertical migration of zooplankton, which could help to increase the concentration of ammonia- $N$ is obviously not sufficient to force a phytoplankton bloom. Later, after a break of this stratification by turbulence, some ammonia- $N$ probably returns to 
the photic zone and the autumn bloom can take place, again we find diatoms and green algae.

\section{Role of the Benthos}

A pelagic-benthic coupling can be assumed for these river mouths, where nutrients can be regenerated from microbes or resuspended and thus given back to the pelagic environment (Sapota et al., 2006). The deeper parts receive particulate matter via sedimentation process. However, much of the particulate organic material can be regenerated and particulate inorganic material, e.g., diatom shells, redissolved on the way through the water column. A recycling of $\mathrm{Si}$ in sediments, as well in the water column is regarded as an important process in geochemical cycling and has been proposed by Callender and Granina (1997).

An indication for a strong decomposition in the water column is the fact that only $28 \%$ of surface pigments reach the bottom in the south basin (Fietz et al., 2005b), but nearly $90 \%$ of these pigments could be related to Bacillariophyceae and Chrysophyceae. Ryves et al. (2003) and Batterbee et al. (2005) even assume that only $1 \%$ of the diatoms accumulate in the sediments and many species dissolve (e.g., Nitzschia acicularis) in the water column. Hence, the organic matter is set free for microbial attack and mineralization and thus nutrients, e.g., nitrogen in the form of ammonia, may have a chance to be recirculated to the euphotic zone and to stimulate a regenerated production.

The dominant spring diatoms (A. baicalensis, A. skvortzowii), on the other hand, show high sinking rates with $60-100 \mathrm{~m} \mathrm{~d}^{-1}$ (Ryves et al., 2003), which is in the same order of marine species, which accelerate their sinking rates by aggregate formation (Eppley et al., 1967; Smetacek, 1985). In this case, however, organic material (and recycled nutrients) are lost for the euphotic zone. As A. baicalensis is capable to produce large free-floating macro-aggregations grown in this state, it serves as a preferred food source for bottom invertebrates (Bondarenko et al., 2006), and thus serves in these areas for a link between sediment and water.

Sediments, however, do not show an even seasonal signal. The taxa found can be related well to environmental variables, i.e., ice conditions, radiation etc. (Mackay et al., 2003). Only few data are available about benthic remineralization processes and a process, which might bring back remineralized nutrients to the euphotic zone. Maerki et al. (2006) showed that mineralization occurs in deep water sediments mainly by oxidative processes. But the return of inorganic matter to the euphotic layer is difficult. Deep ventilation has been described only as an episodic event (Killworth et al., 1996) or is due to local thermal bars (Shimaraev et al., 1993). Hence, significant amounts of nutrients from benthic processes are probably restricted to coastal areas such as river mouths.

\section{Remineralisation}

\section{in the water column}

Total C-production can be assumed to be about $20 \mathrm{~g} \mathrm{C} \mathrm{m}^{-1} \mathrm{yr}^{-1}$ in the south basin, and $14 \mathrm{~g} \mathrm{C} \mathrm{m}^{-1} \mathrm{yr}^{-1}$ in the north basin, respectively (Müller et al., 2005, ILEC). These figures underpin the oligotropic character of the lake which is assumed to be due to a lack of available phosphate (Müller et al., 2005) and have been confirmed by Straskrabova et al. (2005). Low concentrations of phosphate $\left(<15-20 \mathrm{mg} \mathrm{L}^{-1}\right.$ $\left.\mathrm{PO}_{4}-\mathrm{P}\right)$ have also been described as sporolation threshold for Aulacoseira skvotzowii (Jewson et al., 2008). Such figures have to be related to the occurring secondary production either by direct feeding of herbivorous zooplankton or via heterotrophic uptake of exudates by bacteria which then are consumed by protozooplankton which enters the food chain by carnivorous or 
omnivorous zooplankton. This latter link, known as the microbial loop, was under investigation by Straskrabova et al. (2005) and presents the only intensive view on the abundance view on these critical items of the microbial loop. High amounts of dissolved organic carbon have been reported by Yoshioka et al. (2002), but not clearly related to its sources.

Due to these patterns (Silow, 1999, Moore et al., 2009) and, in more detail, Yoshii et al. (1999) describe different but straight - ,simple“ - food webs from phytoplankton to top consumers for the pelagic and the benthic system, the latter underpins this finding from studies with stable isotopes. Yoshii et al. (1999) just present five steps, expressed by five ecological groups, i.e., phytoplankton (A. baicalensis), mesozooplankton (Epichura baicalensis), macrozooplankton (Macrohectopus branickii), fish (Coregonus autumnalis), and the seal (Phoca sibirica). There is much evidence that limnoecology of Lake Baikal works basically at these levels, as this sustains an empiric observation of the food web. Nevertheless, the bypass by the microbial loop cannot be ignored, as we see high amounts of dissolved organic matter and - at least for some time - the occurrence of protozooplankton. Figures of production rates show a decrease from low primary production $\left(2100 \mathrm{mg} \mathrm{m}^{-2} \mathrm{yr}^{-1}\right)$ to bacterial production ( $748 \mathrm{mg} \mathrm{m}^{-2} \mathrm{yr}^{-1}$ ), herbivorous zooplankton (178 $\left.\mathrm{mg} \mathrm{m}^{-2} \mathrm{yr}^{-1}\right)$, carnivorous zooplankton $\left(10 \mathrm{mg} \mathrm{m}^{-2} \mathrm{yr}^{-1}\right)$ and fish $\left(4 \mathrm{mg} \mathrm{m}^{-2}\right.$ $\left.\mathrm{y}^{-1}\right)$ (ILEC).

\section{External impacts}

The impact of global warming has also reached Lake Baikal with effects on mean annual temperature of air and water with consequences on ice duration and biological features (Moore et al., 2009). These authors also describe the subsequent steps in physical and biological oceanographic patterns, like the shift to earlier dates of the spring and summer bloom onsets of phytoplankton. An increase in radiation is followed by an increase in water temperature and thus water stratification and water mixing in the lake's basins. Longer periods have positive effects on primary production, phytoplankton growth and succession. Such increase in average water temperature by $1.21{ }^{\circ} \mathrm{C}$ since 1946 is reported by Hampton et al. (2008) with consequences on chlorophyll $a$ contents and different zooplankton grazers. A negative influence can be expected on the growth of the spring bloom diatom Aulacoseira skvotzowii which is cold adapted and its mortality will increase at temperature above $6.5^{\circ} \mathrm{C}$ (Jewson et al., 2008). Autotrophic picoplankton has proposed as indicators for ecosystem health in general (Munawar et al., 1994), hence, survey studies should keep an eye on this group of organisms.

\section{Summary}

This review showed a strong evidence for a strong local diversity in Lake Baikal's pelagic and benthic biology. The location of the lake and the different seasonal and local effects make it difficult to analyse the available data with respect to a comprehensive biological view. The concern is especially true for the shifting phytoplankton spring blooms from south to north as well as for the widely uncoupled benthic-pelagic systems, i.e., the pelagic system in the photic zone. The decoupling can be regarded as a main factor for the nutritional oligotrophic regime of Lake Baikal. In order to analyse the pelagic food web with respect to an active microbial loop and the nutrient recovery from deep lake environments, new approaches in research are needed. This is especially necessary, when coping the new environmental problems of global warming and increasing anthropological inputs into the lake. Studies on sedimentation, nutrient and pollution 
recovery from the deep layers might become a serious problem in near future when the mixing zone might shift to deeper layers due to strong impacts from atmospheric events.
Acknowledgements. The authors would like to thank participants for fruitful discussions during the Symposium "Problems of Ecology", held September 20-25 ${ }^{\text {th }}$, Irkutsk, 2010.

\section{References}

Ahn T.S., Kim O.S., Joh K.S., Spiglazow L.P., Drucker V.V., Hing S.-H. 2006. Community analysis of aggregated bacteria in southern Lake Baikal. Hydrobiologia 568: 5-8

Azam F., Fenchel T., Field J.G., Gray J.S., Meyer-Reil L.-A., Thingstad F. (1983) The ecological role of water-column microbes in the sea. Mar. Ecol. Progr. Ser. 10: 257-263

Batterbee R.W., Mackay A.W., Jewson D.H., Ryves D.B., Sturm M. (2005) Differential dissolution of Lake Baikal diatoms: correction factors and implications for palaeoclimatic reconstruction. Glob. Planet Change 46: 75-86

Belykh O.I., Sorokovikova E.G. (2003) Autotrophic picoplankton in Lake Baikal: Abundance, dynamics, and distribution. Aquat. Ecosyst. Health Managem. 6: 251-261

Belykh O.I, Ekaterina G., Sorokovikova T., Saphonova A., Tikhonova I.V. (2006) Autotrophic picoplankton of Lake Baikal: composition, abundance and structure. Hydrobiologia 568: 9-17

Bondarenko N.A., Timoshkin O.A., Röpsdorf P., Melnik N.G. (2006) The under-ice and bottom periods in the life cycle of Aulacoseira baicalensis (K. Meyer) Simonsen, a principal Lake Baikal alga. Hydrobiologia 568: 107-109

Callender E., Granina L. (1997) Geochemical mass balance of major elements in Lake Baikal. Limnol. Oceanogr. 43: 148-155

Dugdale R.C., Goering J.J. (1967) Uptake of new and regenerated forms of nitrogen in primary production. Limnol Oceanogr 42:196-206

Epply R.W., Holmes R.W., Strickland J.D.H. (1967) Sinking rates of marine phytoplankton measured with a fluorometer. J Exp. Mar. Biol. Ecol. 1: 191-208

Fietz S., Kobanova G., Izmest'eva L., Nicklisch A. (2005a) Regional, vertical and seasonal distribution of phytoplankton and photosynthetic pigments in Lake Baikal. J. Plankt. Res. 27: 793810

Fietz S., Sturm M., Nicklisch A. (2005b) Flux of lipophilic photosynthetic pigments to the surface sediments of Lake Baikal. Glob. Planet Change 46: 29-44

Granina L. (1997) The chemical budget of Lake Baikal: a review. Limnol. Oceanogr. 42: 373378

Hampton S.E., Izmest'eva L., Moore M.Y., Katz S.L., Dennis B., Silow E.A. (2008) Sixty years of environmental change in he world's largest freshwater lake - Lake Baikal, Siberia. Glob. Change Biol. 14: 1-12

Heim B., Oberhaensli H., Fietz S., Kaufmann H. (2005) Variation in Lake Baikal's phytoplankton distribution and fluvial input assessed by SeaWiFS satellite data. Glob. Change Biol. 46: 9-27

Hohmann R., Kipfer R., Peeters F., Piepke G., Imboden D.M., Shimaraev M.N. (1997) Processes of deep-water renewal in Lake Baikal. Limnol. Oceanogr. 42: 841-855

ILEC - International Lake Environment Committee Foundation, «World Lakes Database», www. ilec.or.jp 
Izmestyeva L., Silow E. (2010) Long-term dynamics of summer community of Baikal phytoplankton and climate change. 13th World Lake Papers. Shiga: ILEC. 4 p. http://wldb.ilec.or.jp/ data/ilec/WLC13_Papers/others/9.pdf

Jewson D.H., Granin N.G., Zhadow A.A., Gorbunova L.A., Bondarenko N.A., Gnatovsky R.Yu. (2008) Resting stages and ecology of the planktonic diatom Aucaloseira skvortzowii in Lake Baikal. Limnol. Oceanogr. 53: 1125-1136

Killworth P.D., Carmack E.C., Weiss R.F., Matear R. (1996) Modelling deep-water renewal in Lake Baikal. Limnol. Oceanogr. 41: 1521-1538

Kozhov M.M. (1963) Lake Baikal and its life. The Hague: W. Junk Publishers, 344 p.

Kozhova O.M., Izmest'yeva L.R., Eds. (1998) Lake Baikal: Biodiversity and Evolution. Leiden: Backhuys Publishers, $447 \mathrm{p}$.

Kozhova O.M. (1987) Phytoplankton of Lake Baikal: Structural and Functional Characteristics Arch. Hydrobiol. 25: 19-37

Mackay A.W., Battarbee R.W., Flower R.J., Granin N.G., Jewson D.H., Ryves D.B., Sturm M. (2003) Assessing the potential for developing internal diatom-based functions for Lake Baikal. Limnol. Oceanogr. 48: 1183-1192

Maerki M., Müller B., Wehrli B. (2006) Microscale mineralization pathways in surface sediments: A chemical sensor study in Lake Baikal. Limnol. Oceanogr. 51: 1342-1354

Maksimenko S.Yu., Zemskaya T.I., Pavlova O.N., Ivanov V.G., Buryukhaev S.P. (2008) Microbial community of water column of the Selenga River-Lake Baikal biogeochemical barrier. Microbiol. 77: 587-594

Margalef R. (1979) The organization of space. Oikos 33: 152-159

Melnik N.G., Bondarenko N.A., Belykh O.I., Blinov V.V., Ivanov V.G., Korovyakova I.V., Kostornova T.Ya., Lazarev M.I., Logacheva N.F., Pomazkova G.I., Sherstyankin P.P., Sorokovikova L.M., Tolstikova L.I., Tereza E.P. (2006) Distribution of pelagic invertebrates near a thermal bar in Lake Baikal. Hydrobiologia 568: 69-76

Moore M.V., Hampton S.E., Izmest'eva L.R., Silow E.A., Peshkova E.V., Pavlov B.K. (2009) Climate change and world's ,sacred sea“ - Lake Baikal, Siberia. Bioscience 59: 1-13

Müller B., Maerki M., Schmid M., Vologina E.G., Wehrli B., Wüest A., Strum M. (2005) Internal carbon and nutrient cycling in Lake Baikal: sedimentation, upwelling, and early diagenesis. Glob. Planet Change 46: 101-124

Munawar M., Munawar I.F., Weisse T., Leppard G.G., Legner M. (1994) The significance and future potential of using microbes for assessing ecosystem health: The great lakes example. J. Aquat. Ecosyst. Health 3: 295-310

Nagata T., Takai K., Kawanobe K., Kim D.-S., Nakazato R., Guselnikova N., Bondarenko N., Mologawaya O., Kostrnova T., Drucker V., Satoh Y., Watanabe Y. (1994) Autotrophic picoplankton in southern Lake Baikal: abundance, growth and grazing mortality during summer. J. Plankton Res. 16: 945-959

Popovskaya G.I. (2000) Ecological monitoring of phytoplankton in Lake Baikal. Aquat. Ecosyst. Health Managem. 3: 215-225

Richardson T.L., Gibson C.E., Heaney S.I. (2000) Temperature, growth and seasonal succession of phytoplankton in Lake Baikal, Siberia. Freshwater Biol. 44: 431-444 
Russell M., Russell-Mele A. (2005) Preliminary study of fluxes of major lipid biomarker classes in the water column and sediments of Lake Baikal, Russia. Glob. Planet Change 46: 45-56

Ryves D.B., Jewson D.H., Sturm M., Battarbee R.W., Flower R.J., Mackay A.W., Granin N.G. (2003) Quantitative and qualitative relationships between planktonic diatom communities and diatom assemblages in sedimenting material and surface sediments in Lake Baikal, Siberia. Limnol. Oceanogr. 48: $1643-1661$

Sapota T., Hakanson L., Aldahan A., Possnert G. (2006) Sediment flux to Lake Baikal (Siberia, Russia): Modelling approach. Geomorphology 80: 105-113

Semovski S.V., Mogilev N.Yu., Shertsyankin P.P. (2000) Lake Baikal ice: analysis of AVHRR imaginary and simulation of under-ice phytoplankton bloom. J. Mar. Syst. 27: 117-130

Shimaraev M.N., Granin N.G., Zhdanov A.A. (1993) Deep ventilation of Lake Baikal waters due to spring thermal bars. Limnol. Oceanogr. 38: 1068-1072

Shimaraeva S., Izmestyeva R., Silow E. (2010) Long-term dynamics of under-ice community of Baikal phytoplankton and climate change. 13th World Lake Conference Papers. Shiga: ILEC. 4 p. http://wldb.ilec.or.jp/data/ilec/WLC13_Papers/others/13.pdf.

Silow E.A. (1999) The use of two lumped models for the analysis of consequences of external influences on the Lake Baikal ecosystem. Ecol. Model. 121: 103-113

Silow E.A., Baturin V.A., Stom D.J. (2001) Prediction of Lake Baikal ecosystem behaviour using an ecosystem disturbance model. Lake Reserv. Res. Managem. 6: 33-36

Smetacek V. (1985) Role of sinking in diatom life-history cycles: ecological, evolutionary and geological significance. Mar. Biol. 84: 239-251

Steele J.H. (1974) The structure of marine ecosystems. Cambridge: Harvard University Press.

Straskrabova V., Izmest'eva L.R., Maksimova E.A., Fietz S., Nedoma J., Borovec J., Kobanova G.I., Shchetinina E.V., Pisllegina E.V. (2005) Primary production and microbial activity in the euphotic zone of Lake Baikal (Southern Basin) during late winter. Glob. Planet Change 46: 57-73

Wetzel R.G. (2001) Limnology: Lake and River Ecosystems. Third Edition. N.Y.: Academic Press.

Wüest A., Lorke A. (2010) Small-scale turbulence and mixing: energy fluxes in stratified lakes. In: Likens G.E., Ed. Lake ecosystems ecology. A global perspective. N.Y.: Academic Press, 107114.

Yoshii K., Melnik N.G., Timoshkin O.A., Bondarenko N.A., Anoshko P.N., Yoshioka T., Wada E. (1999) Stable isotope analyses of the pelagic food web in Lake Baikal. Limnol. Oceanogr. 44: $502-511$

Yoshioka T., Ueda S., Khodzher T., Bashenkhaeva N., Korovyakova I., Sorokovikova L., Gorbanova L. (2002) Distribution of dissolved organic carbon in Lake Baikal and its watershed. Limnology 3: 159-168 


\title{
Существует ли микробная петля
}

\section{в озере Байкал?}

\author{
М. Болтера ${ }^{\text {, Л.Р. Изместьева }}{ }^{\mathbf{\sigma}}$ \\ ${ }^{a}$ Институт полярной экологии, \\ Университет Христиана-Альбрехта, \\ Германия 24148, Киль, Вишхоф шттр. 1-3 \\ ${ }^{\sigma}$ НИИ биологии, \\ Иркутский государственный университет, \\ Россия 664003, Иркутск-3, а/я 24
}

Обсуждается существование микробной петли в пелагиали в связи как с гидрологическими и метеорологическими факторами, так и с состоянием планктона в разныле сезоны в оз. Байкал. Условия, в которых происходит таяние льда и ход весеннего развития планктона, указывают на наличие сильной связи между фитопланктоном и бактериями. Тем не менее отсутствие данных по микрозоопланктону и появляющиеся сообщения о роли разных групп, вовлеченных $в$ микробиальную петлю, затрудняют получение общей картины потоков веществав озере. Кроме того, скорость погружения диатомовых водорослей не дает возможности реминерализации планктонных углерода и азота в фотическом слое. Таким образом, минерализованные бактериями биогенные вещзества долгое время пребывают в абиссали озера, что и может приводить к олиготрофности верхних слоев. 